Review Article

\title{
ETHNOMEDICINAL, PHYTOCHEMICAL AND PHARMACOLOGICAL ASPECTS OF FLACOURTIA JANGOMAS: A REVIEW
}

\author{
SAJEESHA SASI, NISHAT ANJUM, Y. C. TRIPATHI
}

Chemistry Division, Forest Research Institute, P. O. New Forest, Dehradun 248006, India Email: tripathiyc@gmail.com

Received: 21 Apr 2017 Revised and Accepted: 01 Feb 2018

\begin{abstract}
Flacourtia jangomas (Lour.) Raeusch., a small tree of Willow family distributed throughout tropical regions of East Africa and Asia is well-known for its culinary and medicinal uses. The plant has received increasing interest due to its limonoid constituents. Phytochemical studies have led to the isolation and characterization of an array of bioactive compounds and pharmacological investigations have validated the traditional uses of the species as well as discovered some new bioefficacies. The aim of the review is to present an updated and comprehensive overview of traditional uses, ethnomedicinal significance, phytochemical and pharmacological aspects of $F$. jangomas to highlight its ethnopharmacological use and to explore its therapeutic potentials thereby providing a basis for future research. Relevant information and literature on $F$. jangomas from electronic databases such as Academic Journals, Google, Google Scholar, PubMed, Web of Science, and Science Direct were consulted and analyzed. Available literatures evidently demonstrate that $F$. jangomas possess a wide spectrum of pharmacological activities that could be explained by the presence of varied range of chemical constituents. Phytochemical and pharmacological investigations showed that extracts of different parts and major active components of $F$. jangomas had antimicrobial, analgesic, antidiabetic, antidiarrheal, antioxidant and cytotoxic activities. This emphasizes the need for further investigation to explore more bioactive chemical constituents and new bioefficacies of the plant and to establish a credible relationship between molecular structure and activity of compounds.
\end{abstract}

Keywords: Flacourtia jangomas, Traditional uses, Ethnomedicine, Phytochemistry, Pharmacology

(c) 2018 The Authors. Published by Innovare Academic Sciences Pvt Ltd. This is an open access article under the CC BY license (http://creativecommons.org/licenses/by/4.0/) DOI: http://dx.doi.org/10.22159/ijpps.2018v10i3.23998

\section{INTRODUCTION}

Plants have been used as a source of medicine from ancient to contemporary age. Initially, these were the main part of folk or ethanomedicine, practiced in India and other parts of the world like China, Middle East Africa and South America. Later, substantial part of such indigenous knowledge were organized, documented and eventually passed into the organize systems of medicines such as Ayurveda, Chinese, Yunani, Sidha, Tibetan or other systems [1]. Despite significant development of rural health services, village people still use herbal folk medicines to a good extent for treatment of common ailments like cough, cold and fever, headache and body-ache, constipation and dysentery, burns, cuts and scalds, boils, ulcers, skin diseases and respiratory troubles and others [2]. Nevertheless, a growing world-wide interest in the use of phytopharmaceuticals as complementary or alternative medicine, either for prevention or amelioration of many diseases has been noted in recent years [3]. Among the plants often used in traditional medicine, Flacourtia jangomas (Lour.) Raeusch. Belonging to the genus Flacourtia is known to have diverse therapeutic value. The genus Flacourtia comprises of 15 species of shrubs and small trees of flowering plants in the Willow family, Salicaceae [4]. The genus was formerly named in the honour of Étienne de Flacourt (1607-1660), a governor of Madagascar and was placed in the now defunct family Flacourtiaceae [5]. It is native to the African and Asian tropics and subtropics. Several species of the genus are cultivated for their fruits and as ornamentals. They are especially loved in Caribbean, where locals utilize its fruits in drinks and dishes [6]. Some species of Flacourtia originate in India as well. It spread to other parts of the world, including Sri Lanka, Puerto Rico, northern South America, Florida, and China [7]. In this review, the ethnomedicinal, phytochemical and pharmacological aspects of $F$. jangomas are presented.

Flacourtia Jangomas-plant profile

Taxonomical classification

\begin{tabular}{lll}
\hline Kingdom & $:$ & Plantae \\
Subkingdom & $:$ & Viridiplantae \\
Infrakingdom & $:$ & Streptophyta (Land plants) \\
Superdivision & $:$ & Embryophyta \\
Division & $:$ & Tracheophyta (Vascular plants) \\
Subdivision & $:$ & Spermatophytina (Spermatophyes) \\
Class & $:$ & Magnoliopsida \\
Superorder & $:$ & Rosanae \\
Order & $:$ & Malpighiales \\
Family & $:$ & Salicaceae (Willows) \\
Genus & $:$ & Flacourtia \\
Species & $:$ & jangomas \\
\hline
\end{tabular}

Synonyms: Flacourtia cataphracta Roxb. ex Willd., Stigmarota jangomas Lour. [8]

Common names: Indian plum, Indian coffee plum [8] 
Vernacular names

\begin{tabular}{lll}
\hline Languages & Names \\
\hline Arabic & $:$ & Talisfir, Zarnab \\
Assamese & $:$ & Paniyal \\
Bangladesh & $:$ & Painnagola \\
Bengali & $:$ & Tipafol, Luluki \\
Brazilian & $:$ & Yun Nan Ci Li Mu \\
Chinese & $:$ & Talispatri \\
English & $:$ & Chankali, Goraji \\
Hindi & $:$ & Jagam \\
Kannada & $:$ & Heitroi \\
Konkani & $:$ & Lubica, Lovlolika, Vayyamkaitha sour cherry \\
Manipuri & $:$ & Champeran \\
Malayalam & $:$ & Baincha \\
Marathi & $:$ & Sruvavrksha, Vikankatah \\
Oriya & $:$ & Vaiyyankarai \\
Sanskrit & $:$ & Kuragayi \\
Tamil & $:$ & Takhob \\
Telugu & & \\
Thai &
\end{tabular}

$[9,10]$

\section{Botanical description}

F. jangomas (Lour.) Raeusch commonly known as Paniala or Indian plum or Coffee plum belongs to the family Flacourtiaceae (now placed in Salicaceae) $[11,12]$. It is a small deciduous tree growing up to $6-10 \mathrm{~m}$ but occasionally reach up to $14 \mathrm{~m}$ in height. Trunk and branches of old trees are thornless whereas woody thorns are present when young. The bark is light brown to copper-red or pinkish buff, flaking into thin lamels, smooth and lenticelled. Yung branches are white dotted by numerous suborbicular lenticels, puberulous or mostly glabrous. Petiole is 6.0-8.0 mm long and leaves are alternate, deciduous, pale pink when young, spirally arranged, rarely ovate-lanceolate, long point toothed, very thin, both surfaces glossy, blade elliptic, serrate, $7.0 \mathrm{~cm}-11.0 \mathrm{~cm} \times 3.5 \mathrm{~cm}-4.0 \mathrm{~cm}$, pappery and show 3-6 pairs of secondary nerves. Inflorescence is axillary racemes $1.0-2.0 \mathrm{~cm}$ long, subcorymbose, glabrous, few flowered, the male $1.5-3.0 \mathrm{~cm}$ and the female $1.0-1.5 \mathrm{~cm}$ long. Flowers are dioecious, white to greenish in colour comprising 4 or 5 ovate triangular petals bearing fragrance of honey before or with the young foliage. Pedicels are very slender, 0.5-1 $(-1.5 \mathrm{~cm})$. Sepals 2 $\mathrm{mm}, 4-5$ in number are ovate, obtuse, greenish, and pubescent on both sides. Disk is fleshly entire or slightly lobed and is white or yellow (orange) coloured. Male flowers are filaments, glabrous and solitary or in clusters while female flowers are solitary. Male and female flowers are on separate trees. The androecium consists of many anthers, which are ovate to suborbicular. Ovary is 4-6 celled, with two ovules per locule which are initially flask shaped, soon subglobular, with 4-6 styles connate into a distinct, $1 \mathrm{~mm}$ high column, not or slightly free at their apices, each bearing a dilate, bilobed, recurved stigma. Flowers appear from December to April together with new leaves with very beautiful fresh green colour.

Fruits are ellipsoid berries, subglobose, $1.5-2.5 \mathrm{~cm}$ in diameter, dullbrownish red or purple, then blackish, with greenish-yellow pulp ripening from March to July, enclosing 4-5(-10) flat seeds. Seeds are tipped with the single, short style-column with 4-6 minute stigma points $[13,14]$. The tree is propagated through seeds. However, seeds are slow to germinate; therefore propagation is usually by inarching or budding onto self-seedlings. Ripe fruits are eaten by birds and widely dispersed thus facilitating very wide distribution of the species [15].

\section{Origin and distribution}

F. jangomas is lowland semi-cultivated fruit tree with uncertain wild confinement. Its wild organ is unknown however it is said to have originated from India and distributed throughout tropical regions of East Africa and tropical Asia. It is indigenous to North-eastern Terai region of Utter Pradesh, Bihar Maharashtra, Bengal, Assam and Orissa states and some parts of South India. It is often found in the Brahmaputra valley of Assam and adjoining areas of Northeast region of India [16]. It has naturalized in areas such as Hawaii, New
Caledonia, Cook Islands, La Reunion and warmer coastal districts of eastern Australia where it is occasionally cultivated usually as a rare and exotic fruit tree [17].

\section{Traditional uses}

F. jangomas is well-known for its edible juicy fruits with pleasant tart flavour. The fruits are dark-red or purple when ripe and eaten raw or used for making jams and preserves $[5,18]$. The flesh is firm, brownish green and fairly juicy. It is stewed as dessert, made into juice, syrup, jam, marmalade, pickles, and sauces. Sometimes, fruits may be astringent; so, they are rolled between the hands to reduce astringency. When slightly under-ripe, it is used to make jellies. In India, fruits find immense culinary and medical importance, especially in Kerala $[19,20]$. The acidic young shoots are eaten in Indonesia. The wood is red or scarlet, closed grained, hard, brittle, durable, and polishes well. It is used for agricultural implements or block. The wood is sometimes harvested for lumber in the Indian states of Tamil Nadu, Kerala and Karnataka. It is often used as a cheaper alternative to Teak and other expensive wood. The plant is considered one of the primary host plants of Bactrocera tryoni, the Queensland fruit fly [17].

\section{Ethnopharmacology}

F. jangomas is an important fruit tree having immense nutritional and medicinal significance. In the Indian system of medicine, fruits are regarded as alleviator of vitiated doshas and toxic conditions. The fruits are used in bilious conditions and in diarrhoea. It is also used in the treatment of bleeding gum, toothache, diabetes and the leaves after decoction are used in the treatment of diarrhoea, dysentery and piles [10]. Different parts of the plant are pharmaceutically used for the treatment of asthma, pre-and post-natal blood purification and many other ailments [21]. Barks are used for the treatment of intermittent fever. The roots are sweet, refrigerant, depurative alexipharmic and diuretic. They are useful in asthma, anaemia and so on. The leaves and young shoots, which taste like rhubarb, are astringent and stomachic. The fruits are used to overcome digestive disorders, allay thirst, biliousness, fevers, nausea and diarrhoea [22, 23]. The leaf decoction is taken to halt diarrhoea. Powdered roots are used as poultice on sores and skin eruptions and held in the mouth to soothe toothache. Decoction of the bark is useful in biliousness, bleeding gums, toothache, piles and weakness of limbs [24]. The leaves and bark are used in the treatment of diarrhoea, bleeding gums, toothache, piles and weakness of limbs and applied on bleeding gums and aching teeth, and the bark infusion is gargled to alleviate hoarseness [25]. Powdered dried leaves are employed to relieve bronchitis and cough. Fruits hold a notable status in the treatment of stomachic and digestive; allay thirst, useful in biliousness, fevers and relieves nausea. The fruits are eaten in Burma to promote digestion. In India, dried leaves are used to treat asthma [26]. In Malaysia, a decoction of leaves is used as a drink to treat diarrhoea, to promote digestion and the juice 
squeezed from the roots is used to treat herpes infection. In Cambodia, Laos, and Vietnam, a decoction of the leaves is used as a drink to abort, or the fruits are eaten for the same purpose. A paste of roots is applied to sores, ulcers, and to soothe an inflamed throat. Fruits are given in jaundice and enlarged spleen. Ground bark paste is also used for curing many common ailments in the Tribal settlements of Western Ghat. Fruits are also used in liver related disorders [23].

The plant is astringent, acrid, sour, refrigerant, and stomachic and used for a variety of, ailments like diarrhoea, inflammation, skin disease, jaundice, tumours, nausea, dyspepsia and diabetes in south Indian traditional medicine [27]. Leaves and young shoots which taste like rhubarb are astringent and stomachic. The leaves and bark are slightly acid and acrid are useful for bleeding gums and toothache. The leaves and bark and reported to be useful in diarrhoea, piles, weakness of limbs, bleeding gums, stomatitis. An infusion of bark is used as gargle [28].

\section{Phytochemistry}

F. jangomas is one among that plants which have not been adequately explored scientifically. Work on phytochemical aspects of the plant has been found scanty [28, 29]. In fact, plants of the family Flacourtiace received attention only during the last few years following the discovery of a series of cytotoxic diterpenes from Casearia sylvestris [30-32]. However, phytochemical reports are still limited to a few species and not much is understood about the chemistry of the family. Studies so far have shown that the Flacourtiaceae elaborates a diverse array of compound classes which include terpenoids, alkaloids, flavonoids and tannins, lignans and flavanolignans, glucosides, coumarins and isocoumarins. The plant contains tannin and a fixed oil whereas the bark principally contains tannins; leaves and young shoots are also rich in tannins [22]. There have also been reports of xanthones, quinones, limonoids and phenazines. Two limonoids, namely limolin and jangomolide were reported from the stem and bark of $F$. jangomas [26]. The bioactive compounds including corymbulosine, tremulacin, hydnocarpic acid, chaulmoogric acid have been reported in $F$. jangomas [33]. The fruit and stem bark yielded a coumarin named ostruthin [34]. The phenolic glucoside ester, flacourtin was reported in bark whereas, a butyrolactone lignan disaccharide named ramontoside and steroids including $\beta$-sitosterol and its $\beta$-Dglucopyranoside were reported in the heartwood [34\}. Fruits were reported to be rich in nutrients, protein, fat, sugars (fructose, $\alpha$-and $\beta$-glucose and sucrose), amino acids, vitamin $C$ and minerals including calcium, potassium, phosphorous, iron, magnesium, sodium, manganese, copper, and zinc $[22,35]$. Analysis of fatty acids in fats revealed the presence of palmitic, hexadecadienoic, stearic, oleic, linoleic, alpha-linolenic, and a few minor unidentified acids. Further, amino acids from extract of dried ripe fruits showed the presence of proline, hydroxyproline, methionine, alanine, glycine, and valine. Paper chromatography studies on simple reducing sugars and their alditol acetates indicated the presence of arabinose, glucose, fructose and galactose [36]. The ripe fruits of $F$. jangomas contain good amount of potassium, having high bioavailability and thus, may serve as a good source for sufficient potassium intake [23]. Studies revealed that leaves and stem of the plant contain secondary metabolites such as carbohydrate, steroids, tannins, saponins and phenolic acid and flavonoids like quercetin, luteolin and rutin $[37,38]$. It also constitutes coumarins, xanthones, quinones, phenazins, lignans, flavanolignans, isocoumarins [39]. Fruits are having anthocyanin, alkaloids, $\beta$-carotene, flavonoids, tannins, saponins, amino acids and phenolic compounds which prove it a good antioxidant and thus having good reducing power [40]. Unripe fruits also contain phytochemicals like flavonoids, alkaloids, tannins and total phenols [41]. F. gangomas fruits from Bangladesh were investigated for physicochemical properties and mineral content [42]. Phytochemical screening of methanolic extract of fruits from Assam, India revealed the presence of flavonoids, phenols, tannins, terpenoids and saponins; presence of alkaloids however was not recorded. Methanol extract of the fruits was found to contain most of the bioactive compounds and the total phenol and flavonoid contents were found to be $20 \mathrm{mg} / \mathrm{g}$ and $2 \mathrm{mg} / \mathrm{g}$ respectively [43]. Chemical constituents isolated and characterized from different parts of $F$. jangomas are illustrated in table 1 .

Table 1: Phytochemical isolated from Flacourtia jangomas

\begin{tabular}{|c|c|c|c|c|c|}
\hline Phytochemical groups & $\begin{array}{l}\text { Name of } \\
\text { phytochemicals }\end{array}$ & $\begin{array}{l}\text { Molecular } \\
\text { formula }\end{array}$ & Molecular structure & $\begin{array}{l}\text { PubChem } \\
\text { CID }\end{array}$ & References \\
\hline Limonoid & Limonin & $\mathrm{C}_{26} \mathrm{H}_{30} \mathrm{O}_{8}$ & & 179651 & 26 \\
\hline Limonoid & Jangomolide & $\mathrm{C}_{26} \mathrm{H}_{28} \mathrm{O}_{8}$ & & 91895448 & 26 \\
\hline Diterpene & Corymbulosine & $\mathrm{C}_{34} \mathrm{H}_{52} \mathrm{O}_{8}$ & & 2865 & 33 \\
\hline $\begin{array}{l}\text { Salicinoid } \\
\text { Phenolic } \\
\text { glycoside }\end{array}$ & Tremulacin & $\mathrm{C}_{27} \mathrm{H}_{28} \mathrm{O}_{11}$ & & 442544 & 33 \\
\hline Phenolic glucoside ester & Flacourtin & $\mathrm{C}_{20} \mathrm{H}_{22} \mathrm{O}_{9}$ & & 13889568 & 34 \\
\hline
\end{tabular}




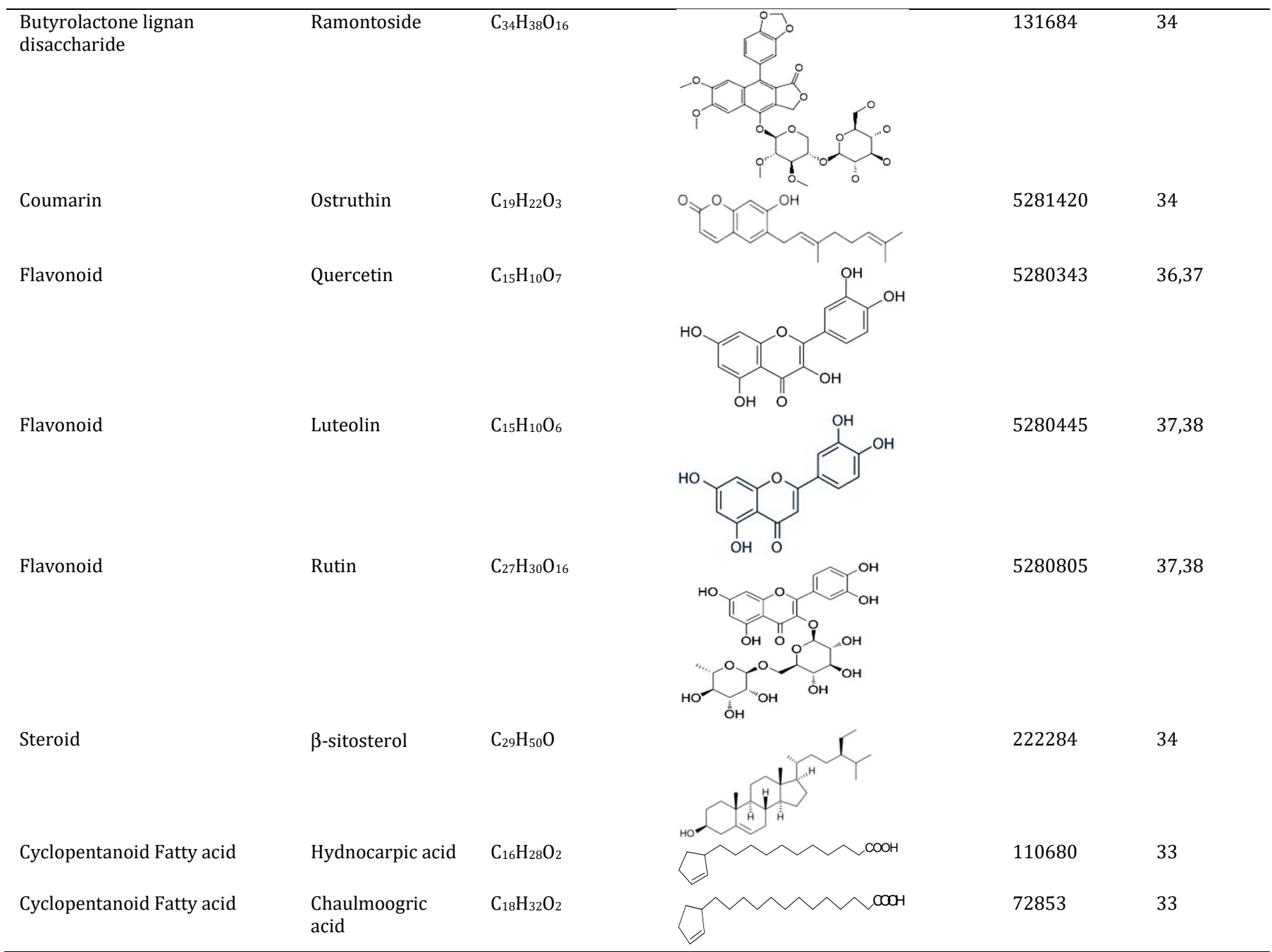

\section{Pharmacology}

F. jangomas is pharmacologically regarded as astringent, acrid, refrigerant, stomachic, diaphoretic, analgesic, stomachic, antiinflammatory, and antimicrobial. It is used for the treatment of skin diseases, diarrhoea, toothache, jaundice asthma and tumours [44]. Fruits are traditionally considered to be antidiabetic [45]. The ripe fruits have high fiber content together with good protein content, low fat and higher amount of monounsaturated fatty acids as compared to polyunsaturated fatty acids. It contains a significant amount of beta-carotene followed by lutein and zeaxanthin, retinol and phylloquinone (vitamin $\mathrm{K}$ ) which are important in the regulation of hemoglobin and fibrinogen in the human body. Besides, ascorbic acid (vitamin C) and niacin (vitamin B3) are also present in significant amounts. Ripe fruits contain a good amount of potassium which has a definite role in the regulation of blood pressure followed by phosphorus and magnesium having their role in controlling osteoporosis. The plant and some of its active chemical constituents have been investigated for various pharmacological properties including analgesic, anti-inflammatory, antibacterial, anti-diarrheal, antiviral, antioxidant, and anti-amylase activity [45]. Pharmacological studies of various parts of the plant as summarized hereunder.

\section{Antibacterial activity}

Antibacterial activity of the crude extract of $F$. jangomas has been studied against both gram-positive and gram-negative bacteria, which showed good antibacterial activity against Shigella shiga and Bacillus megaterium and moderate activity against Bacillus cerus and poor activity against Escherichia coli [39]. Further, there is also report about the chloroform fraction of the root exteact showing strong antimicrobial activity against pathogenic bacteria [46]. Fruit extract of the plant reported to exhibit good antimicrobial activity against Pseudomonas aeruginosa, Klebsiella pneumonia and E. coli [47]. In another study, bacterial endophytes FjF2 and FjR1 isolated from roots showed broad spectrum antimicrobial activity against clinical pathogens gram positive (Staphylococcus aureus, S. aureus) and gram negative (E. coli, Pseudomonas sp., Proteus vulgaris, Klebsiella sp.,) bacteria thus indicating promising antimicrobial activity of the bacterial endophyte isolates against human pathogenic bacteria [48]. Synthesis of AgNPs utilizing F. jangomas leaf extract and its potential antibacterial effect on pathogenic bacteria E. coli was studied. The synthesized AgNPs was found highly effective against the bacteria [49]. In a recent study, the nbutanol extract of $F$. jangomas fruits showed significant antimicrobial activity against $S$. aureus and $E$. coli as compared to the standard drug, Chloramphenicol [50].

\section{Antifungal activity}

Methanol extracts of different parts of $F$. jangomas including leaf, flower, bark and root were evaluated for antifungal efficacy against Candida tropicalis, a resistant strain that ranks second or third causative agent of many candidal infections and several oral diseases such as dental caries, endodontic infections, periodontal diseases and oral candidiasis [51] using Flucanazole as a reference standard. The most significant or highest antifungal activity was shown by $F$. jangomas flowers as observed from highest inhibition zones when compared to positive control [52].

\section{Antidiabetic activity}

Study on the effect of methanolic extract of $F$. jangomas leaves and stem (1:1) in alloxan-induced diabetic rats using glibenclamide as standard antidiabetic agent. Antidiabetic potency of the extract was 
assessed by fasting blood glucose (FBG) level. The result demonstrated that methanolic extract induces significant decrease of blood glucose level in diabetic rats and this effect was more potent after repeated dose $(200 \mathrm{mg} / \mathrm{kg}$ and $400 \mathrm{mg} / \mathrm{kg})$ administration, a marked reduction of blood glucose level in these rats was achieved after $14 \mathrm{~d}$ of treatment [53]. Efficacy of methanolic extract of $F$. jangomas leaf and stem combination (1:1) in streptozotocin (STZ)-induced diabetic rats was also studied. Oral administration of methanolic extract for $21 \mathrm{~d}$ showed impressive $(\mathrm{P}<0.01)$ hypoglycemic activity and altered biochemical parameters specifically cholesterol and triglycerides were also found to be corrected significantly $(\mathrm{P}<0.05)$. Analysis of urine also revealed the absence of glucose and ketone traces in treated mice [54]. Another study also indicated the potentiality of methanolic extract of $F$. jangomas in treating hyperglycemic rats with elevated blood glucose level, body weight and serum lipid profiles along with liver and muscle glycogen level in normal and diabetic rats. Administration of methanol extract of the plant in a dose of 200 and $400 \mathrm{mg} / \mathrm{kg}$ significantly reduces the glucose level. However, low dose i.e. 100 $\mathrm{mg} / \mathrm{kg}$ did not show significant reduction in blood glucose level. Therefore, the effectiveness of the extract depends on the dose and probably on the accumulative effect of active principles [55].

\section{Anti-amylase activity}

The ethanolic extract of $F$. jangomas fruit in several findings suggested that phenolic synergies may play a role in mediating amylase inhibition and therefore have the potential to contribute to the management of type-2 diabetes [56].

\section{Analgesic activity}

Analgesic activity of the ethanol extract of $F$. jangomas leaves screened by acetic acid induced writhing protocol showed significant inhibition $(\mathrm{P}<0.001)$ of writhing in dose dependent manner as compared with control. The extract exhibited 45.45 and $67.05 \%$ inhibition of writhing at the doses of 250 and $500 \mathrm{mg} / \mathrm{kg}$, respectively while standard diclofenac sodium exhibited $76.14 \%$ inhibition of writhing in experimental mice [38]. The activity assessed by hot plate test showed that leaf extract at the concentration of 250 and $500 \mathrm{mg} / \mathrm{kg}$ and standard morphine (5 $\mathrm{mg} / \mathrm{kg})$ significantly $(\mathrm{P}<0.001)$ increased pain threshold level as compared with control in dose dependent manner. Reaction time was increased from $30 \mathrm{~min}$ and persisted throughout the observation period of $120 \mathrm{~min}$ with gradual decrease of activity with the passage of time. The extract showed maximum reaction time at $60 \mathrm{~min}$ at both doses and standard morphine showed at $90 \mathrm{~min}$ [38].

\section{Antidiarrheal activity}

In vivo antidiarrheal test of ethanolic extract of $F$. jangomas leaves by castor oil induced diarrhoeal model showed significant $(\mathrm{P}<0.001)$ increase in onset of diarrhoea and reduction in frequency of defecation as compared with control in dose dependent manner. The extract exhibited 74.05 and $85.50 \%$ inhibition of defecation at the doses of 250 and $500 \mathrm{mg} / \mathrm{kg}$, respectively while standard loperamide showed $88.00 \%$ inhibition of defection at the dose of 3 $\mathrm{mg} / \mathrm{kg}$ thus clearly indicating promising antidiarrheal activity as substantiated by the prolongation of latent period as compared with control and standard [38].

\section{Antioxidant activity}

Ethanol extract of leaves of $F$. jangomas exhibited a significant DPPH radical scavenging activity in concentration dependent manner with IC50 value of $11 \mu \mathrm{g} / \mathrm{ml}$ whereas the IC50 value for the standard ascorbic acid was $5 \mu \mathrm{g} / \mathrm{ml}$. Total phenol content of the extract was $601.03 \mathrm{mg} \mathrm{GAE} / 100 \mathrm{~g}$ of dried plant material. Also, the extract showed strong ferric reducing power in concentration dependent manner as compared with standard ascorbic acid; which was substantiated by high absorbance increased with the concentration [38]. Methanol extract of fruits showed antioxidant activity against the standard ascorbic acid [50]. A comparative study of total phenol, total flavonoid contents and antioxidant potential of different extracts including chloroform, petroleum ether and methanol extract of $F$. jangomas using DPPH radical scavenging assay, reducing power method, total antioxidant capacity showed moderate to good antioxidant activity of extracts as compared to ascorbic acid. The IC50 value of the chloroform, methanol and petroleum ether extracts were 523.15, 1623.87 and $5811.35 \mu \mathrm{g} / \mathrm{ml}$ respectively while, the IC50 value of well-known antioxidant Ascorbic Acid was $13.37 \mu \mathrm{g} / \mathrm{ml}$. Among the extracts chloroform extract was found displaying strong DPPH radical scavenging action and also exhibited highest phenol and flavonoid content as well as total antioxidant capacity as compared to petroleum ether and methanol extracts [57]. As far as reducing power is concerned, the tested extracts demonstrated antioxidant potential in a dose dependent manner. A study on reducing power of fruits extracts showed enhancement in reducing power with increase in treatment concentration of fruit extracts [58]. Unripe fruit showed the greater reducing of as compared to that recorded for ripe fruits $[59,60] . F$. jangomas fruits from Bangladesh reported to show DPPH free radical scavenging activity with the IC50 value $1.144 \mathrm{mg} / \mathrm{ml}$ [56]. Methanol extract of fruits contain a very good amount of phenolics also showed strong radical scavenging activity [61]. Antioxidant efficacy of different parts of the plant was studied using DPPH and ABTS radical scavenging assay; of which the flower extract of $F$. jangomas showed significant antioxidant potential with IC50 values of $11.16 \pm 0.54 \mu \mathrm{g} / \mathrm{ml}$ and $12.34 \pm 0.37 \mu \mathrm{g} / \mathrm{ml}$ for DPPH and ABTS assays [62].

\section{Cytotoxic activity}

Cytotoxic activity of the ethylacetate extract of $F$. jangomas was investigated following Brine shrimp lethality bioassay technique using Vincristine sulfate as a standard reference indicated significant efficacy in a dose dependant manner. Maximum mortality recorded at a concentration of $80 \mathrm{mg} / \mathrm{ml}$, whereas least mortalities were at $5 \mathrm{mg} / \mathrm{ml}$ concentration [39]. The cytotoxic activity of the extracts was investigated on SCC9 and Calu6 through MTT assay. Methanolic extract of flower showed promising cytotoxic activity against the two cancer cell lines, Calu6 and SCC9 with IC50 values of $43.57 \pm 0.04 \mu \mathrm{g} / \mathrm{ml}$ and $53.42 \pm 0.15 \mu \mathrm{g} / \mathrm{ml}$, respectively. The antiproliferative activity of extracts investigated by analyzing cell cycle through flow cytometry revealed that treatment with methanol extract of flower caused significant arrest in G2M phase of cell cycle [62].

\section{CONCLUSION}

Medicinal plants have been used for centuries as remedies for human diseases because they contain components of therapeutic value. The curative properties of medicinal plants are attributable to the presence of various bioactive phytochemicals which may explain their traditional uses against various ailments. In this review article, effort has been taken to collect and compile the details regarding ethnomedicinal, phytochemical and pharmacological pharmacological facets of $F$. jangomas, a less explored plant [63]; however, has received interest owing to its diverse ethnomedicinal significance and presence of many biofunctional phytochemicals. Literature search has shown that the plant has immense medicinal uses in different systems of medicine in India as well as throughout the world. Bioactive chemical constituents isolated and characterized so far from the plant and a variety of pharmacological activities, including antibacterial, antifungal, analgesic, antidiabetic, antidiarrheal, anti-oxidant and cytotoxic activity are presented in this review. Phytochemical and pharmacological studies of the crude extracts and compounds isolated from $F$. jangomas have received much interest recently. Extensive research with regard to isolation and characterization of the active principles responsible for the activity and to understand the precise mechanism of the therapeutic action is required so that better, safer and cost-effective drugs can be developed. Pharmacological findings evidently indicate that the plant extract and some of its biofunctionl constituents can be formulated which will be useful to the society to venture in to a field of alternative systems of medicine.

\section{AUTHORS CONTRIBUTIONS}

All the author have contributed equally

\section{CONFLICT OF INTERESTS}

Declared none 


\section{REFERENCES}

1. Canter PH, Thomas H, Ernst E. Bringing medicinal plants into cultivation: opportunities and challenges for biotechnology. Trends Biotechnol 2005;23:180-5.

2. Tripathi YC, Puni L. Renaissance in traditional medicine system. MFP News 2010;20:14-9.

3. Tripathi YC, Singh S. Prospecting phytomedicinal diversity: threats and challenges. In: Majumdar DK, Govil JN, Singh VK, Sharma RK. Editors. Recent progress in medicinal plants (Plant Bioactives in Traditional Medicine). Vol. 9. Houston, Texas, USA: Studium Press: LLC; 2005. p. 425-41.

4. The Plant List. Flacourtia. Available from: http://www.theplantlist.org/browse/A/Salicaceae/Flacourtia [Last accessed on 21 Nov 2017]

5. Mitra RL. Flacourtiaceae. In: Sharma BD, Balakrishnan. Editors. Flora of India., Botanical Survey of India, Kolkata; 1933;2:403-5.

6. The Earth of India. All about Flacourtia. Available from: http://theindianvegan.blogspot.in/2012/10/all-about-

flacourtia.html. [Last accessed on 21 Nov 2017]

7. Yang Q, Zmarzty S Flacourtiaceae. In: Wu ZY, Raven PH, Hong DY, editors. Flora of China. Vol. 13. (Clusiaceae through Araliaceae). Science Press/Missouri Botanical Garden Press, Beijing/St. Louis; 2007.p. 118-21.

8. Flacourtia jangomas. Available from: https://en.wikipedia.org/ wiki/Flacourtia_jangomas. [Last accessed on 10 Nov 2017]

9. Sophia T. Flacourtia jangomas description. Flowers of India. Available

from:

http://www.flowersofindia.net/catalog/slides/Coffee\%20Plu m.html [Last accessed on 10 Nov 2017]

10. Kirthikar KR, Basu BD, Taylor LG. Indian Medicinal Plants. 2nd ed. 1. Dehra Dun, India: Bishen Singh Mahendra Pal Singh; 1993. p. 220.

11. Hanelt P. Mansfeld's Encyclopedia of Agricultural and Horticultural Crops: (Except Ornamentals), Institute of Plant Genetics and Crop Plant Research. Eds. Springer; 2001. p. 3700.

12. Chandra I, Bhanja P. Study of organogenesis in vitro from callus tissue of Flacourtia jangomas (Lour.) Raeusch through scanning electron microscopy. Curr Sci 2002;83:476-9.

13. Lim TK. Flacourtia jangomas. In: Edible Medicinal and NonMedicinal Plants. Springer, Dordrecht; 2013. p. 771-5.

14. Baruah D, Neog B. Botanical, phytochemistry and pharmacological review of Flacourtia jangomas (Lour) Raeusch. Int J Curr Med Pharm Res 2016;2:244-7.

15. Hossain MA, Sen S, Jewel MIU, Kabir MA. Propagation of Flacourtia jangomas: an approach towards the domestication of a wild fruit species in Bangladesh. Dendrobiology 2011;65:63-71.

16. Dutta B, Borah N. Studies on nutraceutical properties of Flacourtia jangomas fruits in Assam. India J Med Plants Stud 2017;5:50-3.

17. Botha J, Darryl H, Greg P. Queensland fruit fly Bactrocera tryoni: exotic threat to Western Australia. AGWEST Factsheet. No. 43/2000, The Government of Western Australia; 2000.

18. Singh MP, Nayar MP, Roy RP. Textbook of Forest Taxonomy, New Delhi: Anmol Pub Pvt Ltd; 1994. p. 132.

19. Leung WTW, Butrum RR, Huang Chang F, Narayana Rao M, Polacchi W. Food composition table for use in East Asia. FAO, Rome; 1972 . p. 347.

20. Tee ES, Noor MI, Azudin MN, Idris K. Nutrient composition of Malaysian foods. $4^{\text {th }}$ edn. Kuala Lumpur: Institute for Medical Research; 1997. p. 299.

21. Jain SK. Dictionary of Indian Folk Medicine and Ethnobotany, New Delhi: Deep Publication; 1991. p. 91.

22. Ghani A. Medicinal Plants of Bangladesh. $2^{\text {nd }}$ ed. The Asiatic Society of Bangladesh; 2003. p. 1-17.

23. Srivastava D, Prabhuji SK, Rao GP. Taxonomic and ethnobiological status of Flacourtia jangomas (Lour.) Raeus. an endemic nutraceutical plant of Eastern U. P. medicinal plants. Int J Phytomed Related Industries 2009;1:49-53.

24. Yusuf M, Chowdhury JU, Wahab MA, Begum J. Medicinal plants of Bangladesh, Bangladesh Council of Scientific and Industrial Research. Dhaka, Bangladesh; 1994. p. 340.
25. Yusuf M, Wahab MA, Chowdhury JU, Begum J. Some tribal medicinal plants of Chittagong Hill Tracts, Bangladesh. Bangladesh. J Plant Taxon 2007;14:117-28.

26. Ahmad J, Wizarat K, Shamsuddin KM, Zaman A, Connolly JD. Jangomolide, a novel limonoid from Flacourtia jangomas. Phytochem 1984;23:1269-70.

27. Singh NS, Geetha M, Amudha P, Chakraborty A. Evaluation of anti-diabetic activity of methanol extract of Flacourtia jangomas (lour) in streptozotocin induced diabetic rats. Int J Pharma Biosci 2010;1:1-11.

28. Hasan SK, Sissodia P. Paniala (Flacourtia jangomas) plant extract as eco-friendly inhibitor on the corrosion of mild steel in acidic media. Rasayan J Chem 2011;4:548-53.

29. Dubey N, Pandey VN. Ethnobotanical importance of Flacourtia jangomas (Lour.) Raeusch. Trends Bio Sci 2013;6:532-4.

30. Morita H, Nakayama M, Kojima H, Takeya K, Itokawa H, Schenkel EP, et al. Structures and cytotoxic activity relationship of casearins, new clerodane diterpenes from Casearia sylvestris Sw. Chem Pharm Bull (Tokyo) 1991;39:693-7.

31. Oberlies NH, Burgess JP, Navarro HA, Pinos RE, Fairchild CR, Peterson RW, et al. Novel bioactive clerodane diterpenoids from the leaves and twigs of Casearia sylvestris. J Nat Prod 2002;65:95-9.

32. Santos AGD, Ferreira PMP, Vieira GM Jr, Perez CC, Tininis AG, Silva $\mathrm{GH}$, et al. Casearin $\mathrm{X}$, its degradation product and other clerodane diterpenes from leaves of Casearia sylvestris: evaluation of cytotoxicity against normal and tumour human cells. Chem Biodivers 2010; 7:205-15.

33. Pandey VN, Dubey N. Nutraceutical, pharmaceutical and industrial value of coffee plum: Flacourtia jangomas (Lour.) Raeusch. Everyman's Sci 2014;49:98-104.

34. Khare CP. Indian Medicinal Plants. New York USA: Springer Science Business Media LLC; 2007. p. 270.

35. Kermasha S, Barthakur NN, Mohan NK, Mohan NP. Chemical composition and proposed use of two semi-wid tropical fruits. Food Chem 1987;26:253-9.

36. Dinda B, Banerjee J, Pal J, Mahanti A. Chemical composition of Flacourtia jangomas fruits. J Food Sci Technol 1989;26:334-6.

37. Singh NS, Geetha M, Amudha P, Chakraborty A. Evaluation of anti-diabetic activity of methanol extract of Flacourtia jangomas (lour) in streptozotocin induced diabetic rats. Int J Pharma Bio Sci 2010;1:1-11.

38. Talukdar C, Saha S, Adhikari S, Mondal HK, Islam MK Anisuzzman M. Evaluation of antioxidant, analgesic and antidiarrheal activity of Flacourtia jangomas (Lour.) Raeusch. Leaves. Pharmacol Online Arch 2012;3:20-8.

39. Parvin S, Kader A, Sarkar GC, Gosain SB. In vitro studies of antibacterial and cytotoxic properties of $F$. jangomas. Int J Pharm Sci Res 2011;2:2786-90.

40. Dubey N, Pandey VN. Reducing activity of fruits of Flacourtia jangomas (Lour.) raeusch. Adv Life Sci 2013;2:82-3.

41. Dubey N, Pandey VN, Tewari SK. Antioxidant potential and phytochemical composition of unripe fruits of Flacourtia jangomas (Lour.) Raeusch. Med Plants Int J Phytomed Related Industries 2013;5:164-7.

42. Ara R, Jahan S, Abdullah ATM, Fakhruddin ANM, Saha BK. Physicochemical properties and mineral content of selected tropical fruits in Bangladesh. Bangladesh J Sci Indian Res 2014;49:131-6.

43. Dutta B, Borah N. Studies on nutraceutical properties of Flacourtia jangomas fruits in Assam, India. J Med Plan Stud 2017;5:50-3.

44. Shirona TK, Sruthy KB, Rajendran N. Antibacterial and antioxidant properties of two medicinal plants from Kerala, India. Int J Chem Pharm Sci 2014;5:68-72.

45. Jeyachandran R, Mahesh A. Enumeration of antidiabetic herbal flora of Tamil Nadu. Res J Med Plan 2007;1:144-8.

46. Sarker GC, Zohan R, Alam MB, Islam MS, Mosaddik MA, Haque MEK. Antibacterial activity of Flacourtia jangomas and Flacourtia sepiaria. Int J Pharm Life Sci 2011;2:878-83.

47. Srivastava D, Sheikh S, Prabhuji SK, Rao GP, Tripathi A, Sribastava R. In vitro antibacterial activities of Flacourtia jungomas (Lour.) Raeus. fruit extracts. Medicinal Plants-Int J Phytomed Related Industries 2012;4:98-100. 
48. Shukla S, Naik G, Mishra SK. Potential antimicrobial activity of bacterial endophytes isolated from Flacourtia Jangomas (Lour.) Raeusch, a less explored medicinal plant. J Microbiol Biotechnol and Food Sci 2015;doi: 10.15414/jmbfs.2015.4.6.473-477.

49. Kashyap S, Srivastava A, Saxena PS. Biosynthesis of silver nanoparticles from Flacortia jangomas leaf extract and its bactericidal application against E. coli. Int J Mater Sci 2017;12:104-7.

50. Das S, Dewan N., Das KJ, Kalita D. Preliminary phytochemical, antioxidant and antimicrobial studies of Flacourtia jangomas fruits. Int J Curr Pharm Res 2017;9:86-91.

51. Akpan A, Morgan R. Oral Candidiasis-Review. Postgrad Med J 2002;78:455-9.

52. George SA, Harini BP, Bhadran S. In vitro assessment of antifungal activity of selected botanicals on Candida tropicalis. Intl J Recent Sci Res 2016;7:9863-6.

53. Singh AK, Singh J, George M, Joseph L. Anti-diabetic effect of Flacourtia jangomas extract in alloxan-induced diabetic rats. Pharmacologyonline 2010;2:253-9.

54. Singh AK, Singh J. Evaluation of anti-diabetic potential of leaves and stem of Flacourtia jangomas in streptozotocin-induced diabetic rats. Ind J Pharmacol 2010;42:301-5.

55. Singh NS, Geetha M, Amudha P, Chakraborty A. Evaluation of anti-diabetic activity of methanol extract of Flacourtia jangomas (lour) in streptozotocin induced diabetic rats. Int J Pharm Bio Sci 2010;1:1-11.
56. Aklima J, Mojumder S, Sikdar D. Total phenolic content, reducing power, antioxidative and anti-amylase activities of five Bangladeshi fruits. Int Food Res J 2014;21:119-24.

57. Rahman MM, Habib MR, Hasan MR, Islam AMT, Khan IN. Comparative antioxidant potential of different extracts of Flacourtia jangomas lour fruits. Asian J Pharm Clin Res 2012;5:73-5.

58. Dubey N, Pandey VN. Ferric reducing power of solvent extracts of fruits of Flacourtia jangomas (Lour.) Raeusch. Life Sci Leaflets 2013;10:66-71.

59. Dubey N, Pandey VN, Tewari SK. Antioxidant potential and phytochemical composition of unripe fruits of Flacourtia jangomas (Lour.) Raeusch. Int J Phytomed Related Industries 2013;5:164-7.

60. Murillo E, Britton GB, Durant AA. Antioxidant activity and polyphenol content in cultivated and wild edible fruits grown in Panama. J Pharm Bioallied Sci 2012;4:313-7.

61. Seal T. Antioxidant activities of some wild vegetables of Northeastern region in India and effect of solvent extraction system. Int J Pharm Pharm Sci 2014;6:315-9.

62. George SA, Bhadran S, Sudhakar M, Harini BO. Comprehensive in vitro evaluation of pharmacological activities of selected plant extracts and GC-MS profiling of Flacourtia jangomas flower extract. Asian J Pharm Clin Res 2017;10:237-44.

63. Sauco VG. Global overview of underutilized tropical and subtropical fruits. Acta Hor 2008;770:77-85. 